\title{
PENGARUH SARANA PRASARANA TERHADAP PRODUKTIVITAS KERJA PADA BPJS KESEHATAN CABANG KOTABUMI
}

\author{
Yudiansyah $^{(1)}$, Husna Purnama ${ }^{(2)}$, Fahrizi $^{(3)}$ \\ Fakultas Ekonomi Universitas Sang Bumi Ruwa Jurai \\ yudiansyah.l@gmail.com,husna.purnama@fe.saburai.ac.id,fahrizi@fe.saburai.ac.id
}

\begin{abstract}
Abstrak. Badan Penyelenggara Jaminan Sosial kesehatan (BPJS Kesehatan), sebagai badan yang memenuhi perlindungan dasar kesehatan bagi seluruh masyarakat Indonesia. Oleh karna itu penggunaan sarana prasarana yang efisien dan efektif mampu mempermudah pelaksanaan pekerjaan, sehingga kinerja organisasi akan dapat mewujudkan tujuannya. Peningkatan produktifitas tersebut dapat meningkatkan pula produktifitas secara keseluruhan, Sarana Prasana yang baik diharapkan dapat meningkatan produktifitas kerja pegawainya Kerja. Tujuan dari penelitian ini adalah untuk mengetahui pengaruh sarana prasarana terhadap produktivitas kerja pada BPJS Kesehatan Cabang Kotabumi. Hasil pengujian menunjukkan bahwa persamaan regresi linier sederhananya adalah $\mathrm{Y}=8,757+0,638(\mathrm{X})$. Pengujian hipotesis dilakukan dengan menggunakan uji $\mathrm{t}$ yang menunjukkan bahwa sarana prasarana berpengaruh terhadap produktifitas kerja. Dari hasil olah data dapat diketahui bahwa tingkat signifikansi sebesar $0,00<0,05$ dengan nilai thitung >ttabel yaitu 11,802>2,012, dengan demikian sarana prasarana berpengaruh terhadap produktifitas kerja pada BPJS Kesehatan Cabang Kotabumi.
\end{abstract}

Kata kunci: Aktivitas, Sarana, Prasarana, Produktif.

\section{PENDAHULUAN}

Perkembangan dunia kesehatan di Indonesia cukup kompleks karena melibatkan berbagai pihak di dalam negeri sekaligus bagian dari perkembangan dunia kesehatan secara global. Perubahan dan perkembangan tersebut terjadi dengan cepat dan luas. BPJS Kesehatan, merupakan suatu lembaga dengan ciri khasnya yang tersebar di seluruh wilayah Indonesia. BPJS Kesehatan yang semakin menguatkan peran dan kompetensinya di bidang penyedia jasa dan pemberian kualitas pelayanan kesehatan. Maka dari itu BPJS Kesehatan harus mampu memberikan pelayanan bagi peserta dan masyarakat secara efektif dan efisien dan tetap bermutu dan berkualitas.

Penyelenggaraan program jaminan sosial khususnya Jaminan Kesehatan Nasional (JKN) merupakan salah satu tangung jawab dan kewajiban Negara untuk memberikan perlindungan social ekonomi kepada masyarakat. Sesuai dengan kondisi kemampuan keuangan negara. Indonesia seperti halnya Negara berkembang lainnya, mengembangkan program jaminan social berdasarkan funded social security, yaitu jaminan sosial yang didanai oleh pekerja dan pemberi kerja serta yang tidak mampu dibiayai negara. Badan Penyelenggara Jaminan Sosial (BPJS) dibidang kesehatan, sebagai badan penyelenggara jaminan social kesehatan yang memenuhi perlindungan dasar kesehatan bagi seluruh penduduk Indonesia.

Kepuasan peserta merupakan salah satu faktor yang menentukan tingkat keberhasilan dan kualitas layanan dalam program ini. Keberhasilan dalam memberikan layanan yang berkualitas kepada masyarakat, peningkatan Kepercayaan dan Kepuasan Peserta tersebut ditentukan oleh pendekatan yang digunakan konsekuensi atas pendekatan kualitas jasa suatu produk atau jasa menjadi hal yang 
utama bagi strategi organisasi untuk mempertahankan diri dan mencapai kesuksesan dalam menghadapi tantangan global. Salah satu pendekatan kualitas jasa yang banyak dijadikan acuan dalam riset pemasaran adalah model SERVQUAL (Service Quality). SERVQUAL dibangun diatas adanya perbandingan dua faktor utama yaitu persepsi pelanggan atas layanan yang nyata mereka terima dengan layanan yang sesungguhnya diharapkan. Jika kenyataannya lebih dari yang diharapkan maka layanan dapat dikatakan berkualita, dan sebaliknya.

Suatu organisasi harus membuat perencanaan sarana prasarana dengan baik, agar fasilitas yang dipilih sesuai dengan kebutuhan. Perencanaan sarana prasarana merupakan suatu kegiatan yang dilakukan sebelum dan sesudah operasi. Secara umum perencanaan fasilitas mempunyai beberapa fungsi seperti menunjang kegiatan produksi, menggunakan tenaga kerja, peralatan dan ruang serta energy secara efektif, meminimalkan investasi modal, mempermudah pemeliharaan, meningkatkan keselamatan dan kepuasan kerja.

BPJS Kesehatan Cabang Kotabumi menggunakan berbagai macam sarana prasarana kerja untuk meningkatkan produktivitas kerja dan ketepatan waktu pengerjaan tugas oleh pegawai. Dengan tersedianya sarana prasarna yang terdapat pada BPJS Kesehatan Cabang Kotabumi menyebabkan peningkatan produktivitas kerja secara terus-menerus dan akan berpengaruh terhadap meningkatnya kepercayaan dan kepuasan masyarakat.

Peningkatan produktifitas kerja tersebut pada akhirnya dapat meningkatkan kepuasan dan kepercayaan masyarakat secara keseluruhan, Sarana Prasana yang baik diharapkan akan dapat meningkatkan produktifitas kerja pegawainya. Ketika produktifitas pegawai telah tercapai maka organisasi dapat mengukur sejauh mana peningkatan produktifitas kerja yang mereka capai. Hal inilah yang menjadi alur dasar penelitian yang akan dikembangkan oleh penulis, dimana penulis menduga terdapat pengaruh antara sarana prasarana terhadap peningkatan produktifitas kerja pegawai.

Produktifitas kerja merupakan suatu masalah yang harus mendapatkan perhatian serius dari pihak organisasi, karena peningkatan produktifitas kerja itu tidak akan terjadi dengan sendirinya, tetapi harus ada usaha dan peran yang baik dari BPJS Kesehatan Cabang Kotabumi maupun dari pihak internal organisasi itu sendiri. Salah satu cara untuk dapat meningkatkan produktifitas kerja pegawai adalah dengan cara peningkatan sarana prasaran yang baik dan memadai untuk menunjang produktifitas kerja yang baik.

Berdasarkan uraian tersebut maka peneliti tertarik untuk melakukan peneliti dengan judul: "Pengaruh Sarana Prasarana Terhadap Produktivitas Kerja Pada BPJS Kesehatan Cabang Kotabumi".

\section{KAJIAN TEORI}

\section{Definisi Sarana dan Prasarana}

Fasilitas kerja, adalah hal-hal yang berhubungan atau ada dalam lingkungan pekerjaannya dan dapat mempengaruhi dirinya dalam menjalankan tugas yang diberikan, baik itu yang berhubungan dengan kebendaan atau fisik maupun yang berhubungan dengan manusia. Fasilitas kerja yang diharapkan adalah yang aman, tentram, bersih, tidak bising, terang dan bebas dari segala macam ancaman dan gangguan yang menghambat operasional kerja pegawai. Untuk dapat bekerja dengan baik pegawai harus mendapat fasilitas yang cukup tersedia. Pegawai dapat memberikan tanggapan tentang fasilitas apa yang diterima oleh panca indra misalnya 
melihat, mendengar dan merasa. Untuk dapat menanggapi dengan baik terhadap fasilitas tersebut baik positif atau negatif .

Tanggapan terhadap fasilitas yang tersedia dimaksudkan bagaimanakah pegawai melihat, mendengar dan merasakan terhadap fasilitas yang digunakan untuk melaksanakan pekerjaan. Jika mereka menanggapi secara senang maka senantiasa mereka bekerja dengan senang dan sungguh-sungguh.

Sebaliknya, jika mereka menanggapi dengan negatif artinya mereka tidak dapat diharapkan mampu bekerja dengan baik. Fasilitas yang ada di suatu instansi dapat dilihat, dipikir, dan dirasakan atau dimanfaatkan oleh segenap karyawan mulai dari pimpinan hingga pegawai yang paling bawah.

Tanggapan ini dapat positif dan negatif, tanggapan terhadap fasilitas yang tersedia dimaksudkan bagaimanakah pegawai melihat, mendengar dan merasakan terhadap fasilitas yang digunakan untuk melaksanakan tugas. Jika mereka menanggapi secara senang senantiasa bekerja dengan senang dan sungguh-sungguh. Sebaliknya, jika mereka menanggapi dengan negatif, atau mereka tidak dapat diharapkan mampu bekerja dengan baik.

Fasilitas yang ada di suatu unit kerja dapat dilihat, dipikir, dan dirasakan atau dimanfaatkan oleh paea pegawai mulai dari pimpinan hingga pegawai yang paling bawah. Fasilitas yang ada untuk melaksanakan tugas dan tanggung jawab pegawai merupakan salah satu stimulus terhadap semua pegawai.

Selanjutnya, setiap pegawai mereaksi terhadap stimulus tersebut. Karena pegawai memiliki latar belakang yang berbeda-beda (misalnya pendidikan, pengalaman, masa lampau, sosial/ekonomi), akhirnya reaksi terhadap stimulus berbeda-beda. Persepsi adalah proses dimana seseoran mengorganisasi dan menafsirkan pola stimulus dalam lingkungan (Rita L dkk, 2008) menyebutkan bahwa persepsi adalah proses pemberian arti terhadap stimulus yang diterima oleh seorang individu. Pernyataan ini senada dengan pernyataan Crow and Crow (2010) yang menyatakan bahwa persepsi adalah proses pengorgnisasian dan penginterpertasian data sensoris yang didasari oleh hasil pengalaman sebelumnya.

Sebagai makhluk sosial, pegawai mempunyai dua kebutuahan sosial yang pokok, yaitu rasa bersatu dan dukungan. Rasa bersatu akan didapat dengan mengadakan komunikasi tentang apapun yang berhubungan dengan pekerjaan dapat dikerjakan bersama-sama. Sedangkan dukungan dapat diperoleh dari rekan kerja, atasan atau bahkan bawahan, baik berupa penghargaan maupun berupa bantuan jika sedang dibutuhkan. Hal ini dapat menjadi suatu motivasi bagi pekerja dalam melaksanakan tugasnya.

Dari uraian diatas terlihat bahwa fasilitas kerja yang khususnya berupa hubungan kerja yang baik dapat menjadikan suatu cara pemenuhan kebutuhan pekerja untuk mencapai kinerja optimal. Bangunan gedung permanen yang kokoh dengan penataan jendela dan pintu yang menjamin kelancaran peredaran udara dengan lampu penerangan yang cukup serta penataan ruang yang baik dan bersih akan memberi pengaruh positip kepada penghuninya. Sebaliknya gedung yang kurang terawat dengan kondisi ruang yang kurang bersih dan tidak tertata rapih akan berpengaruh negatif.

Halaman dan kebun merupakan pandangan pertama bagi setiap pendatang. Kebersihan halaman dan kebun mencerminkan kadar budaya bersih dari lebaganya. Agar dapat memberi pengaruh positip terhadap kerja pegawai, halaman dan kebun perlu dibenahi sedemikian rupa sehingga terdapat saluran pembuangan yang sehat. 
Pada halaman dan kebun perlu dibuatkan saluran pembuangan air yang sehat, pertamanan yang baik, dan ditanami pepohonan rindang, dengan pola yang sesuai, sehingga tampak selalu bersih, rindang, indah dan tidak becek jika hujan. Lebih baik jika dilengkapi dengan tersedianya kran-kran air yang diatur penempatannya pada segala penjuru halaman dan kebun.

Lokasi tempat kerja juga berpengaruh pada pekerjaannya. Lokasi kerja yang mudah dijangkau oleh kendaraan umum lebih membantu pekerja daripada lokasi yang sukar dijangkau oleh kendaraan umum. Fasilitas kerja sangat diperlukan untuk terlaksananya pekerjaan dengan lancar dan tepat waktu. Makin lengkap fasilitas kerja yang disediakan oleh lembaga makin meningkatkan produktivitas lembaga tersebut. Tersedianya tata tertib yang harus ditaati oleh semua pekerja, merupakan suatu kebutuhan. Dengan tata tertib semua karyawan dapat menempatkan diri dalam pelaksanaan tugasnya dan termotivasi untuk bekerja lebih baik.

Rancangan ruang kerja ukurannya ditetapkan dengan kaki persegi untuk setiap karyawan. Secara historis, Penentu yang paling penting atas ruang yang disediakan bagi karyawan adalah status. Semakin tinggi hierarki seseorang pada organisasi semakin besar pula kantor yang umumnya dia dapatkan. Dewasa ini ketika ruang tambahan dialokasikan, kecenderungan dewasa ini bahwa ruang itu bukannya diberikan ke individu-indivudu tertentu, melainkan dikhususkan sebagai tempat pertemuan orang dan tempat tim-tim yang dapat digunakan untuk sosialisasi pertemuan kelompok kecil atau tempat para anggoata tim membicarakan masalah. Penataan ukuran ruangan juga merujuk pada ukurran besarnya ruangan per karyawan, penataan merujuk ke jarak antara orang dan fasilitas.
Privasi sebagian merupakan fungsi dari besarnya ruang per orang dan pengaturan ruangan itu. Namun privasi juga dipengaruhi oleh dinding dan sekatansekatan fisik lainnya. Salah satu trend rancangan ruang kerja yang paling tersebar luas di tahun-tahun terakhir adalah menghapuskan setahap demi setahap kantor-kantor yang tertutup dan menggantikannya dengan rancangan kantor yang terbuka yang memiliki sedikit sekat atau dinding.

\section{Definisi Produktivitas Kerja}

Produktivitas adalah perbandingan antara hasil yang didapat dengan sumber daya yang diperlukan (Payaman J. Simanjuntak, 2010). Produktivitas mengandung pengertian sikap mental yang selalu mempunyai pandangan bahwa mutu kehidupan hari ini harus lebih baik dari hari kemarin dan hari esok lebih baik dari hari ini. Secara umum produktivitas mengandung pengertian perbandingan antara hasil yang dicapai dengan keseluruhan sumber daya yang dipergunakan (J. Ravianto, 2011).

Produktivitas adalah kemampuan seperangkat sumber-sumber ekonomi untuk menghasilkan sesuatu atau diartikan juga sebagai perbandingan antara pengorbanan (input) dengan penghasilan (output) (John Soeprihanto, 2012). Dari pendapat tersebut dapat disimpulkan bahwa produktivitas adalah perbandingan antara hasil yang didapat dengan sumber daya yang dipergunakan.

\section{Faktor Faktor yang Mempengaruhi Produtktivitas kerja}

Produktivitas tenaga kerja dipengaruhi oleh berbagai faktor yang berhubungan dengan tenaga kerja itu sendiri maupun yang berhubungan dengan lingkungan perusahaan dan kebijaksanaan pemerintah 
secara keseluruhan, seperti pendidikan, keterampilan, disiplin, sikap dan etika kerja, motivasi, gizi dan kesehatan, tingkat penghasilan, jaminan sosial, lingkungan dan iklim kerja, hubungan industrial dan kebijaksanaan pemerintah tentang produksi, investasi, perizinan, teknologi, fiskal, harga, distribusi dan lain-lain (Payaman J. Simanjuntak, 2010).

Sedangkan menurut pendapat J. Ravianto yaitu :

a. Latar belakang pendidikan dan latihan.

b. Alat-alat produktivitas yang digunakan dan teknologi dalam proses produksi.

c. Sistem nilai, nilai-nilai sosial masyarakat atau juga faktor lingkungan hidup tenaga kerja.

d. Lingkungan pekerjaan atau iklim kerja

e. Derajat kesehatan (kesehatan lingkungan), nilai gizi makanan, saitasi, tersedianya air bersih.

f. Tingkat upah yang berlaku.

Faktor-faktor yang dapat mempengaruhi tingkat produktivitas teanga kerja antara lain pendidikan dan latihan keterampilan, gizi / nutrisi dan kesehatan, bakat atau bawaan, motivasi/kemauan, keterampilan kerja, kesempatan manajemen dan kebijakan pemerintah (John Suprihanto, 2012).

Faktor-faktor tersebut dapat mempengaruhi produktivitas baik secara langsung tidak langsung. Produktivitas tenaga kerja dipengaruhi pula tingkat kehadiran karyawan dalam tempat kerja dipengaruhi pula tingkat kehadiran karyawan dalam tempat kerja atau absensi karyawan. Produktivitas tidak mungkin tercapai secara optimal jika tingkat kehadiran karyawan sangat rendah, karena karyawan tidak masuk kerja, secara optimal tidak akan menghasbiskan produk / jasa seperti yang diharapkan.

Dari uraian diatas disimpulkan bahwa agar produktivitas tenaga, kerja dapat ditingkatkan maka hal-hal yang harus diperhatikan :

a. Kualitas dan kemampuan fisik tenaga kerja.

b. Sarana pendukung, yang meliputi antara lain :

1. Kerja antara lingkungan lain berupa sarana, peralatan produksi, teknologi dan keadaan lingkungan kerja.

2. Pemenuhan dan kesejahteraan dan kebutuhan tenaga kerja antara lain berupa jaminan sosial, tunjangan sistem pengupahan, pemberian invensive yang tepat dan pemenuhan kebutuhan-kebutuhan yang lain.

3. kemampaun manajemen dalam menggunakan sumber-sumber daya yang ada secara maksimal dan menciptakan sistem kerja yang baik.

\section{METODE PENELITIAN}

\section{Objek Penelitian}

Objek penelitian ini adalah pegawai di BPJS Kesehatan Cabang Kotabumi, yang beralamat di Jln. Dahlia Nomor 117A Kota Gapura Kotabumi Lampung Utara Penelitian ini di laksanakan dari bulan April sampai dengan Agustus 2018.

\section{Metode dan Teknik Pengumpulan Data}

Dalam penelitian ini jenis data yang diperlakukan adalah :

a. Data Primer

Data primer merupakan data dasar yang akan diperoleh langsung tanpa perantara orang atau lembaga lain sebagai pihak ketiga. Data primer ini diperoleh dengan wawancara melalui responden dengan menggunakan daftar pertanyaan.

\section{b. Data Sekunder}

Data skunder merupakan data yang diperoleh melalui orang lain yang 
berhubungan dengan permasalahan yang dipecahkan. Data sekunder ini diperoleh melalui cara studi dokumenter yaitu mengumpulkan dan mempelajari brosurbrosur serta dokumen organisasi.

\section{Sampel dan Populasi}

Sampel penelitian adalah sebagian dari populasi yang mewakili sifat dan karakter yang sama. Dengan mengambil sampel dimaksudkan untuk menyederhanakan jumlah subyek yang harus diteliti, tetapi hasil penelitian terhadap sampel itu akan digeneralisasikan pada populasi yang ada. Untuk menentukan banyak sampel, peneliti menggunakan pedoman dari pendapat Suharsimi Arikunto (2010), apabila subyeknya kurang dari 100, lebih baik diambil semua sehingga penelitiannya merupakan penelitian populasi. Selanjutnya jika jumlah subyeknya besar, dapat diambil $10 \%-15 \%$ atau $20 \%-25 \%$ atau lebih. Pengambilan sampel dalam penelitian ini adalah seluruh pegawai yang ada di BPJS Kesehatan Cabang Kotabumi yaitu sebanyak 47 orang pegawai.

\section{Metode Analisis Data}

Untuk pengolahan data dalam bentuk tabulasi hasil jawaban responden kemudian dilakukan analisis data melalui metode analisis secara kualitatif dan analisa kuantitatif. Analisis kualitatif dilakukan dengan analisis tabel tunggal atau secara parsial yang akan menggambarkan kriteria masing-masing variabel. Analisis kuantitatif yang dilakukan berdasarkan data primer yang diperoleh dari penyebaran instrument (daftar pertanyaan) kepada sampel, dan untuk mengetahui pengaruh dari variabel bebas (independent variable) terhadap variabel terikat (dependent variable).
Persamaan Regresi Linear Sederhana menentukan persamaan regresi linear sederhana untuk X :

$$
Y=a+b X+e
$$

Keterangan:

$$
\begin{aligned}
& \mathrm{Y}=\text { Produktivitas kerja } \\
& \mathrm{a}=\text { Konstanta } \\
& \mathrm{b}=\text { Koefisien regresi } \mathrm{X} \\
& \mathrm{X}=\text { Sarana Prasarana } \\
& \mathrm{e}=\text { Faktor kesalahan }
\end{aligned}
$$

Untuk mengetahui besarnya pengaruh, penghitungan koefisien korelasi tersebut kemudian dilanjutkan dengan Rumus Koefisien Determinasi atau Koefisien Penentu (KP):

$$
K P=(r)^{2} x 100 \%
$$

Untuk menguji secara hipotesis secara parsial digunakan Uji t dengan rumus :

$$
t_{\text {hitung }}=\frac{r \sqrt{N-2}}{\sqrt{1-r^{2}}}
$$

Keterangan:

$$
\begin{array}{ll}
\mathrm{t}_{\text {hitung }} & =\text { Nilai } \mathrm{t} \\
\mathrm{r} & =\text { Koefisien Korelasi } \\
\mathrm{N} & =\text { Jumlah responden }
\end{array}
$$

(Sugiyono, 2008).

Kriteria untuk Uji $\mathrm{t}$ adalah sebagai berikut :

a) Jika $t_{\text {hitung }}>t_{\text {tabel }}$ maka Ha diterima dan Ho ditolak.

b) Jika $t_{\text {hitung }} \leq \mathrm{t}_{\text {tabel }}$ maka Ha ditolak dan Ho diterima.

Taraf signifikan dalam penelitian ini digunakan $\alpha=0,05$ atau 5\%. Yang dimaksud dengan Hipotesis nol (Ho) dan Hipotesis alternatif (Ha) adalah : 
Ho $=r \leq 0=$ Berarti tidak ada pengaruh sarana prasarana terhadap produktivitas kerja

$\mathrm{Ha}=\mathrm{r}>0=$ Berarti ada pengaruh sarana prasarana terhadap produktivitas kerja.

\section{HASIL DAN PEMBAHASAN}

Data penelitian yang telah dikumpulkan kemudian diolah untuk menguji kualitas data berupa uji validitas dan reliabilitas. Hasil menunjukkan bahwa koefisien korelasi pearson moment untuk setiap item butir pertanyaan dengan skor total variabel tunjangan kerja (X), dan kinerja (Y) signifikan pada tingkat signifikan $\alpha 0,05$. Dengan demikian dapat diinterprestasikan bahwa setiap item indikator instrumen masing-masing variabel tersebut valid. Artinya item-item yang tersaji dalam kuesioner benar-benar mampu mengungkapkan dengan pasti apa yang akan diteliti.

Tabel 1. Hasil Uji Validitas Instrumen Variabel Sarana Prasarana

\begin{tabular}{lccc}
\hline Indikator & r hitung & r tabel & Keterangan \\
\hline X11 & 0.827 & 0.514 & Valid \\
X12 & 0.966 & 0.514 & Valid \\
X13 & 0.827 & 0.514 & Valid \\
X14 & 0.827 & 0.514 & Valid \\
X15 & 0.827 & 0.514 & Valid \\
\hline
\end{tabular}

Nilai $r$ hitung lingkungan kerja lebih besar dari $r$ tabel (0.514).

Tabel 2. Hasil Uji Validitas Instrumen Variabel Produktifitas kerja

\begin{tabular}{|c|c|c|c|}
\hline Indikator & r hitung & $\mathrm{r}$ tabel & Keterangan \\
\hline Y11 & 0.533 & 0.514 & Valid \\
\hline Y12 & 0.921 & 0.514 & Valid \\
\hline Y13 & 0.721 & 0.514 & Valid \\
\hline Y14 & 0.921 & 0.514 & Valid \\
\hline Y15 & 0.621 & 0.514 & Valid \\
\hline
\end{tabular}

Tabel 2. Menunjukkan hasil perhitungan seluruh indikator untuk variabel produktifitas kerja adalah lebih besar dari $r$ tabel, sehingga seluruh indikator dinyatakan valid.

\section{Uji Reliabilitas Data}

Nilai reliabilitas konsistensi internal menunjukkan bahwa koefisien Alpha Cronbach dinyatakan reliabel karena lebih besar dari 0,60. Dengan demikian item pengukuran pada masing-masing indikator dalam variabel-variabel penelitian dinyatakan reliabel dan selanjutnya dapat digunakan dalam penelitan.

\section{Analisis Kuantitatif}

Dari pengolahan data statistik maka diperoleh persamaan regresi linier sederhananya adalah $\mathrm{Y}=8,757+0,638$ (X). Nilai konstanta yang diperoleh sebesar 8,757 , hal ini berarti bahwa jika variabel independen (sarana dan prasarana) adalah bernilai nol, maka besarnya produktifitas kerja yang terjadi adalah 8,757. Nilai koefisien regresi variabel sarana dan prasarana (X) sebesar 0,638, hal ini menunjukkan bahwa setiap kenaikan satu satuan sarana dan prasarana akan mengakibatkan produktifitas kerja sebesar 0,638 .

Koefisien determinan $\left(\mathrm{R}^{2}\right)$ digunakan untuk mengetahui kontribusi variabel bebas dalam menjelaskan variabel terikat. Hasil pengujian menunjukkan bahwa nilai $R$ square sebesar 0.756 Nilai $R$ square ini menunjukkan bahwa besarnya kontribusi variabel independen terhadap variabel dependen adalah sebesar 75,6\%, sedangkan sisanya sebesar $24,4 \%$ ditentukan oleh variabel lain yang tidak teridentifikasi dalam penelitian ini.

Uji hipotesis dilakukan untuk menjawab model kelayakan hipotesis penelitian. Pengujian dilakukan dengan 
menggunakan uji $\mathrm{t}$ pada tingkat kepercayaan $95 \%$ atau $\alpha$ sebesar 0,05 . Apabila thitung > ttabel. Maka model dinyatakan layak digunakan dalam penelitian ini dan sebaliknya apabila thitung $<$ ttabel, maka model dikatakan tidak layak, atau dengan signifikan (Sig) $<0,05$ maka model dinyatakan layak digunakan dalam penelitian ini dan sebaliknya apabila signifikan (Sig) > 0,05 maka model dinyatakan tidak layak digunakan.

Hasil pengujian dapat menjawab hipotesis yang menyatakan "Sarana prasarana berpengaruh terhadap produktifitas kerja." Pengujian dilakukan dengan menggunakan uji $t$ yang menunjukkan bahwa Sarana prasarana berpengaruh terhadap produktifitas kerja. Pengujian dilakukan dengan menggunakan uji t pada tingkat keyakinan signifikansi $\alpha$ 0,05 . Hasil menunjukkan bahwa tingkat signifikansi sebesar $0,00<0,05$ dengan nilai thitung $>$ ttabel yaitu 11,802 > 2,012, dengan demikian hipotesis diterima yang berarti sarana prasarana berpengaruh terhadap produktifitas kerja.

\section{KESIMPULAN DAN SARAN}

\section{Kesimpulan}

Berdasarkan hasil penelitian maka dapat disimpulkan bahwa pengujian dapat menjawab hipotesis yang menyatakan "Sarana prasarana berpengaruh terhadap produktifitas kerja pada BPJS Kesehatan Cabang Kotabumi”. Pengujian dilakukan dengan menggunakan uji $\mathrm{t}$ pada tingkat keyakinan signifikansi $\alpha 0,05$. Dari hasil olah data dapat diketahui bahwa tingkat signifikansi sebesar $0,00<0,05$ dengan nilai $\mathrm{t}_{\text {titung }}>\mathrm{t}_{\text {tabel }}$ yaitu $11,802>2,012$, berarti sarana prasarana berpengaruh terhadap produktifitas kerja pada BPJS Kesehatan Cabang Kotabumi. Hasil pengujian menunjukkan bahwa nilai $R$ square sebesar 0.756 Nilai $R$ square ini menunjukkan bahwa besarnya kontribusi variabel independen terhadap variabel dependen adalah sebesar $75,6 \%$, sedangkan sisanya sebesar $24,4 \%$ ditentukan oleh variabel lain yang tidak teridentifikasi dalam penelitian ini.

\section{Saran}

Adapun saran yang diajukan peneliti adalah sebagai berikut:

1. Kepala BPJS Kesehatan Cabang Kotabumi hendaknya mempertimbangan peningkatan sarana prasarana atau fasilitas yang mendukung bagi peningkatan produktifitas kerja.

2. BPJS Kesehatan Cabang Kotabumi hendaknya selalu meningkatkan produktivitas kerja dengan menggunakan sarana prasarana yang telah ada dan digunakan sebaik-baiknya untuk pelayanan kepada masyarakat.

3. Kepala BPJS Kesehatan Cabang Kotabumi hendaknya memberikan fasilitas atau sarana prasarana dalam menunjang kegiatan pelayanan kesehatan kepada peserta BPJS Kesehatan Cabang Kotabumi.

\section{DAFTAR PUSTAKA}

Algifari. 2013. Metode Penelitian dan Survey. Jakarta: Penerbit LP3S.

Arikunto, Suharsimi. 2010. Prosedur Penelitian. Jakarta: Bina Aksara.

Badan Penyelenggara Jaminan Sosial Kesehatan. 2018. https://www.bpjskesehatan.go.id/bpjs/index.php/pages/de tail/2013/4

Crow and Crow. 2010. Human Resources management, (Tract MBA Series / Terjemahan). Jakarta: Gramedia. 
Erwin. 2016. Pengaruh Sarana Prasarana Terhadap Produktifitas Kerja Karyawan Pada PT. Bank Lampung Di Way Kanan.

Ferdinand. 2009. Metodologi Penelitian Bisnis. Jakarta: Erlangga.

Gibson, Ivancevih, dan Donnely. 2008. Organisasi dan Manajemen. Jakarta: Erlangga.

Handoko, T. Hani. 2011. Manajemen Pesonalia. Yogyakarta: BPFE - UGM.

Masroh. 2010. Pengaruh Sarana prasarana Kerja Dalam Meningkatkan produktivitas Kerja Pegawai Pada Kelurahan Kampung Baru Kecamatan Kedaton Bandar Lampung.

Ravianto. 2008. Manajemen Sumber Daya Manusia, Jilid I. Jakarta: Preshindo.

Ravianto. 2011. Manajemen Sumber Daya Manusia, Edisi Revisi. Jakarta: Presshindo.

Sedarmayanti. 2011. Manajemen Sumber Daya Manusia. Jakarta: CV. Masagung.

Simanjuntak, Payaman J. 2010. Ekonomi Sumber Daya Manusia. Jakarta: Penerbit Fakultas Ekonomi Universitas Indonesia.

Situmorang. 2012. Pengantar Manajemen. Jakarta: Gunung Agung.

Soeprihanto, John. 2012. Pengembangan Sumber Daya Insani. Jakarta: Gunung Agung.

Sugiyono. 2012. Metodologi Penelitian Bisnis. Bandung: Alfabeta. 